\title{
Role of Bacterial Bioflocculant on Antibiofilm Activity and Metal Removal Efficiency
}

\author{
R.T.V. Vimala \\ Department of Biotechnology, Bharathidasan University, Tiruchirapalli - 620 024, Tamil Nadu, India.
}

\begin{abstract}
In the present study, bioflocculant derived from bacteria are widely explored in bioremediation such as removing heavy metal and inhibiting biofilm formation. The bacteria isolated from sewage identified as Proteus mirabilis using $16 \mathrm{~S}$ rRNA gene made up of D-Mannose, D-Fructose, D-Sucrose, and D-Galactose could be identified by Gas liquid Chromatography Mass Spectrometry (GCMS). Fourier transform infrared (FTIR) analysis of the bioflocculant indicated the presence of $-\mathrm{COOH},-\mathrm{OH}$, and $-\mathrm{NH}$ groups which showed the characteristic of polysaccharide and protein. The removing percentage of heavy metals achieved by the precipitated bioflocculant were $82.63 \pm 1.20,72.076 \pm 0.42,57.36 \pm 1.05$, and $44.7 \pm$ $1.053 \%$, respectively for $\mathrm{Zn}^{2+}, \mathrm{Cd}^{2+}, \mathrm{Cu}^{2+}$, and $\mathrm{Hg}^{2+}$ at optimum conditions. Bioflocculant were exhibited excellent biofilm inhibition against $P$. aeruginosa where maximum reduction $(73 \%)$ were achieved at the minimum amount of $80 \mu \mathrm{g} / \mathrm{ml}$ dose. Similarly, maximum reduction (80\%) were achieved at the minimum amount of $70 \mu \mathrm{g} / \mathrm{ml}$ dose for $S$. aureus. It was concluded that the bioflocculant produced have the potential in metal removal and biofilm inhibition.
\end{abstract}

Keywords: Heavy metals, Bioflocculant, Flocculation, Antibiofilm, Polysaccharides.

*Correspondence: vimalartvvijay@gmail.com; 9688556627

(Received: 10 July 2019; accepted: 18 August 2019)

Citation: R.T.V. Vimala, Role of Bacterial Bioflocculant on Antibiofilm Activity and Metal Removal Efficiency, J Pure Appl Microbiol., 2019; 13(3): 1823-1830. https://doi.org/10.22207/JPAM.13.3.59

C The Author(s) 2019. Open Access. This article is distributed under the terms of the Creative Commons Attribution 4.0 International License which permits unrestricted use, sharing, distribution, and reproduction in any medium, provided you give appropriate credit to the original author(s) and the source, provide a link to the Creative Commons license, and indicate if changes were made. 


\section{INTRODUCTION}

Microorganisms produced their metabolites are called as bioflocculant during their growth. Non-toxic nature of the bioflocculant are alternative to synthetic flocculant involving in bioremediation and biomedical application ${ }^{1,2}$. Several bacterial species are capable of producing bioflocculant like Alcaligenes latus, Bacillus firmus ${ }^{3}$, Aspergillus sp. ${ }^{4}$, Streptomyces and Cellulomonas. The bioflocculants made up of microbial metabolic products such as glycoprotein and complex carbohydrates ${ }^{6}$. It is mainly affected by environmental factors such $\mathrm{pH}$, Temperature, dosage of inoculum, carbon and nitrogen sources ${ }^{7,8}$. These key factors affecting bioflocculant production varies for different microbial species.

Generally, bacteria produces a variety of polysaccharides which are classified based on location such as, intracellular, extracellular, and capsular polysaccharides. They are produced via different biosynthesis pathways ${ }^{9}$. In addition, polysaccharides can be used as bioflocculant, heavy metal removing agents ${ }^{10}$, bioadsorbents, encapsulating materials. They are high molecular weight biopolymers such as polysaccharide, glycoprotein, glycolipids, and protein flocculants ${ }^{11,12}$. They described that the functional groups identification of the bioflocculant are significant factor for the flocculating activity ${ }^{13}$.

For decades, attention have focused to remove hazardous pollutants to the environment. But, currently practicing chemical and physical methods for removing the metal from the contaminated environments are not environmentally friendly, costly, non-specific ${ }^{14,15}$. In addition, many of these processes are not successful ${ }^{16}$. Therefore, bioflocculant is the best alternative to remove contaminants. Various uses of bioflocculant in bioremediation processes are involved to remove the toxic materials, and heavy metals, synthesis of nanoparticles and biomass recovery ${ }^{2,17-19}$. In addition, bioflocculant could be acted as a way of preventing biofilm formation.

Considering the significance of bioflocculant in metal sequestration and antibiofilm activity, the present study was focused at searching the strain producing the bioflocculant and simultaneously acting as an antibiofilm agent under optimum conditions. Also, amount of metal uptake and biofilm inhibition percentage of the bioflocculant was estimated. Finally, it emphasized to search over the structural and functional components responsible for flocculation and antibiofilm formation.

\section{MATERIALS AND METHODS \\ Identification of Bacterial strains}

Totally, 20 bacterial strains were previously isolated from the wastewater. Potential strain showing highest flocculating activity were screened for further research. Test bacteria were recognized as Proteus mirabilis through partial sequencing of $16 \mathrm{~S}$ rRNA genes. Nucleotide sequences were finally deposited in GenBank (MG996004).

Production and partial purification of bioflocculant Bioflocculant producing media was prepared based on the methods of Zhang et al. ${ }^{20}$. Components of the media such as $\mathrm{KH}_{2} \mathrm{PO}_{4}(2.0 \mathrm{~g})$, Glucose (15.0 g), $\left(\mathrm{NH}_{4}\right)_{2} \mathrm{SO}_{4}(0.2 \mathrm{~g})$, Yeast extract $(0.5 \mathrm{~g}), \mathrm{K}_{2} \mathrm{HPO}_{4}(5.0 \mathrm{~g}), \mathrm{MgSO}_{4} \cdot 7 \mathrm{H}_{2} \mathrm{O}(0.2 \mathrm{~g}), \mathrm{NaCl}$ $(0.1 \mathrm{~g})$, were dissolved in $1 \mathrm{~L}$ of distilled water $(\mathrm{pH}=7)$ under optimum conditions. $0.5 \mathrm{ml}$ culture of $P$. mirabilis isolated from wastewater, inoculated into the medium and kept it for 72 hrs incubation at $30^{\circ} \mathrm{C}, 160 \mathrm{rpm} / \mathrm{min}$. The broth was centrifuged $\left(8000^{\prime} \mathrm{g}, 20 \mathrm{~min}\right)$ to pelletize the cells. The upper portion of the bioflocculant were added with thrice the volume of ethanol. This washing step was repeated several times to obtain the precipitate. Thereafter, they were assayed for flocculation activity.

\section{Characteristics of the bioflocculant}

Carbohydrate content of the bioflocculant using glucose as the standard solution were measured using Phenol-sulfuric acid method ${ }^{21}$. Lowry method was assessed in measuring the protein content of the bioflocculant ${ }^{22}$. The monomeric unit of the bioflocculant was obtained by hydrolysis of the bioflocculant with $\mathrm{HCl}$ at $121^{\circ} \mathrm{C}$ for $2 \mathrm{hrs}$. They were further subjected to the analysis of FT-IR. The scanning electron microscopy (SEM: SUPRA 55 SAPPHIRE; Germany) image of the bioflocculant was obtained.

\section{Gas Chromatograph-Mass Spectrometer}

The extracted samples were subjected to GC/MS analysis (TQ8030, Shimadzu, Japan). For identifying sugars components, carrier gas used was helium the with a flow rate of $1.0 \mathrm{~mL} \mathrm{~min}-1$, maintaining the temperature of $300^{\circ} \mathrm{C}$ with an 
electron ionization mode (70 eV). Compounds were identified by the NIST1 1library database using chromatograms.

\section{Heavy metal removal rate}

The bioflocculant $(0.8 \mathrm{mg} / 100 \mathrm{ml})$ was applied for the bioflocculation test against heavy metal solutions containing $\mathrm{Cd}^{2+}, \mathrm{Zn}^{2+}, \mathrm{Cu}^{2+}$, and $\mathrm{Hg}^{2+}$ at the concentrations of 0-50 mg L-1, respectively. The amount of heavy metals were identified by inductively coupled plasma atomic emission spectroscopy (ICP-AES; iCAP 7000, Thermo Fischer
Scientific, Bremen, Germany). All experiments were repeated thrice. The percentage of heavy metal removal was measured based on the following equation:

$$
\% R=\left(C_{i}-C_{f}\right) / m
$$

Where, $\mathrm{Ci}$-amount of heavy metal of test solution initially; $C_{f}$ - amount of heavy metal of test solution finally; $\mathrm{m}(\mathrm{g})$ is the weight of bioflocculant.

\section{Antibiofilm assay}

Crystal violet assay was performed which was examined to quantify the biofilm inhibition

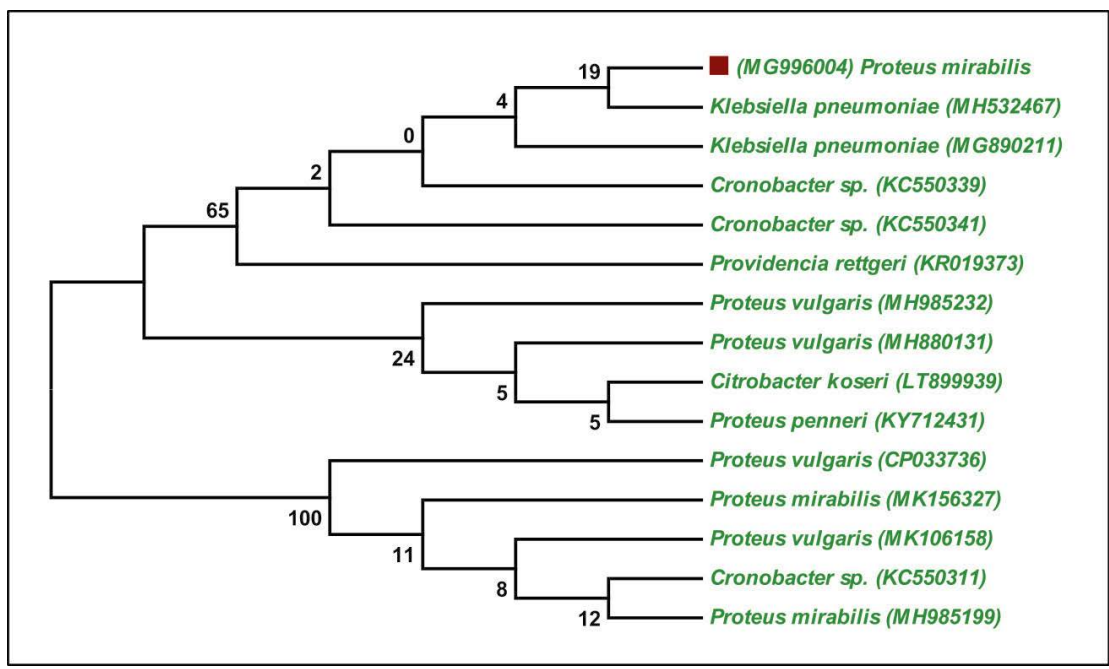

Fig. 1. Phylogenetic tree based on $16 \mathrm{~S}$ rRNA sequences
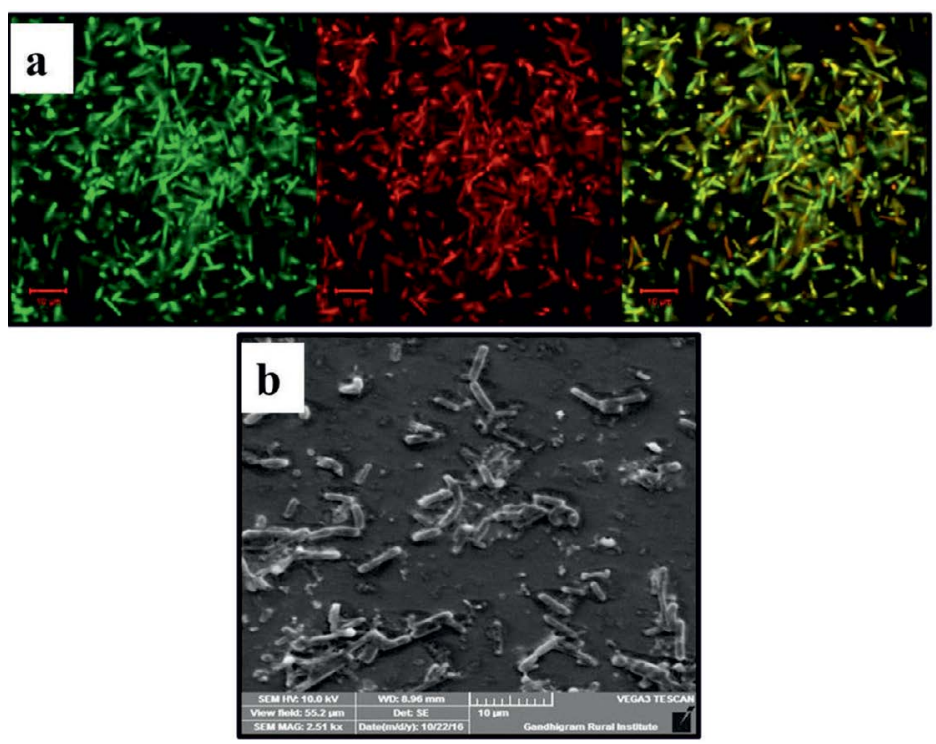

Fig. 2. a) Image of Gram negative bacteria Proteus mirabilis observed under the confocal microscope; b) SEM image of Gram negative bacteria Proteus mirabilis. 
percentage $\mathrm{e}^{23}$

\section{LOD of (OD of} untreated - treated

Biofilm = control) sample) inhibitation OD of untreated control

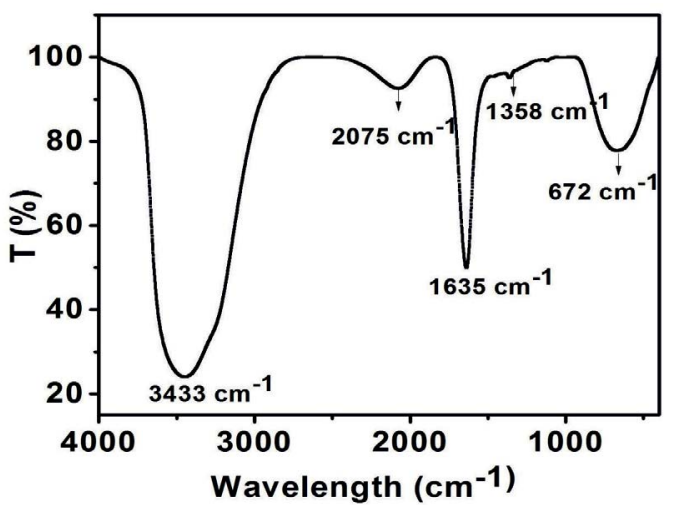

Fig. 3. FTIR spectra of bio occulant showing presence of hydroxyl, amino, and carboxylic group.
Biofilm of Pseudomonas aeruginosa and Staphylococcus aureus grown separately on glass slides in well plates were added with the bioflocculant. They kept the incubation for 24 hrs at $37^{\circ} \mathrm{C}$ and washed with phosphate buffered saline $(0.1 \mathrm{M} ; \mathrm{pH} 7.4)$ to discard non-adherent cells. In the same way, control were also subjected to the same procedure without the bioflocculant. The glass slides were observed under confocal microscopy (CLSM, LSM 510, Carl Zeiss, and Germany) after the Acridine orange staining. All the experiments were conducted thrice.

\section{Production of bioflocculant}

Totally, 20 bacterial strains were isolated from the sewage water. In which, strain showing highest flocculating activity were selected for bioflocculant production. The strain were identified as $P$. mirabilis (MG996004) through $16 S$ rRNA sequence ${ }^{21}$. Phylogenetic tree based on 16S rRNA sequences were constructed (Fig. 1). Morphological structure of $P$. mirabilis were identified (Fig. 2). Totally, 2 g of bioflocculant was obtained from $1 \mathrm{~L}$ fermentation broth
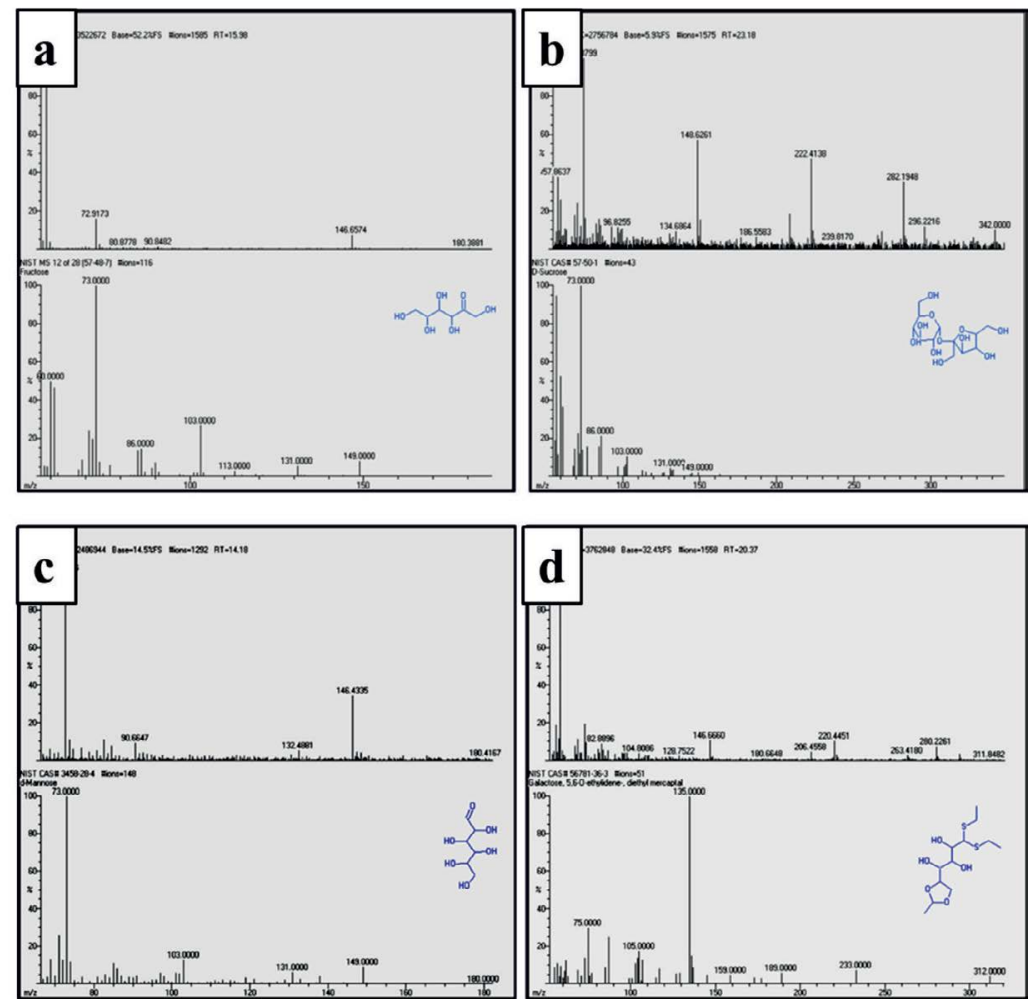

Fig. 4. GC/MS chromatogram of monomeric sugar units identified in the bioflocculant a) D-Fructose, b) D-Sucrose, c) D-Mannose, d) D-Galactose. 
under optimal conditions ${ }^{20}$. The production of bioflocculant was mainly controlled by the factors, such as the components of the culture medium and the cultivation conditions ${ }^{24}$. The key factors, such as the concentration of carbon sources, temperature, shaking speed, nitrogen sources, $\mathrm{pH}$, and inoculum size have to be focused on the flocculating activity of the bioflocculant by Proteus mirabilis ${ }^{25}$.

\section{Characteristics of bioflocculant}

The bioflocculant produced from Proteus mirabilis (MG996004) included 68\% (wt/wt) carbohydrate, and $15 \%$ (wt/wt) protein. These components were confirmed by FTIR spectroscopy by identifying the functional group of the bioflocculant (Fig. 3). The broad peak at $3433 \mathrm{~cm}$ 1 , which was confirmed it as hydroxyl and amino group $^{26}$. Sharp peak observed at $1635 \mathrm{~cm}^{-1}$ was attributed to the characteristic vibration of amide group. Weak peak at $1,358 \mathrm{~cm}^{-1}$ was correlated to the carboxylate group of the bioflocculant ${ }^{27}$. The adsorption band at $672 \mathrm{~cm}^{-1}$ could be related to the binding between sugar monomers ${ }^{28}$. Finally, spectrum revealed the peaks for polysaccharides, protein and identified the presence of the functional groups: hydroxyl (-OH), amide (-CO-NH) and carboxyl (-COO-) ${ }^{25}$. These functional groups act as a binding site for divalent cations, mainly involved in flocculating processes.

$\mathrm{GC} / \mathrm{MS}$ analysis of bioflocculant was found the monomers, viz., D-Mannose, D-fructose, D-Sucrose, D-Galactose (retention times of 14.18, $15.98,23.18$, and $20.37 \mathrm{~min}$, respectively) and compared with NIST Library (Fig. 4). The results indicated that the bioflocculant made up of four sugar monomers ${ }^{29,30}$. HR-SEM showed the outer
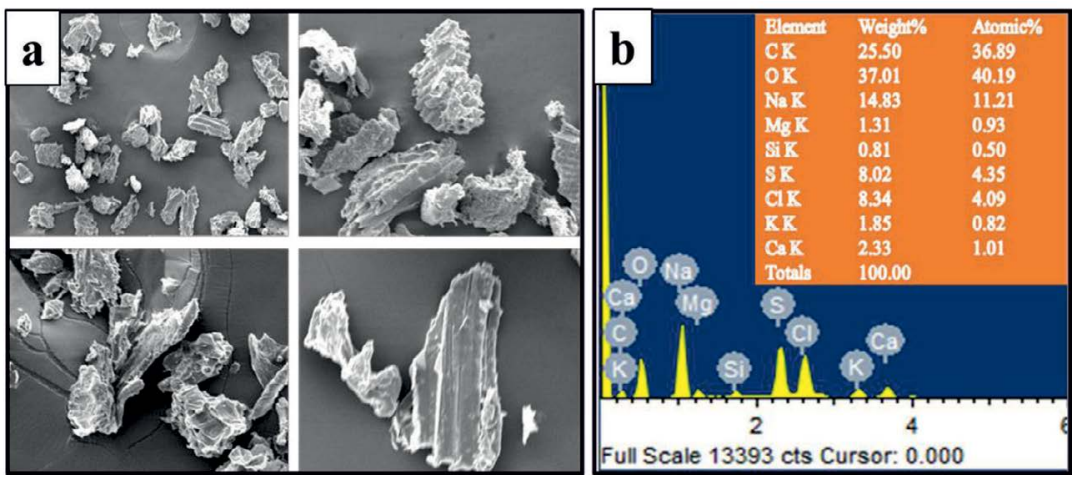

Fig. 5. (a) Irregular shape of the bio occulant; (b) SEM-EDAX spectra depicting the presence of $\mathrm{C}, \mathrm{K}, \mathrm{O}, \mathrm{Na}, \mathrm{Ca}, \mathrm{Mg}$, and $\mathrm{Cl}$ in the bio occulant.

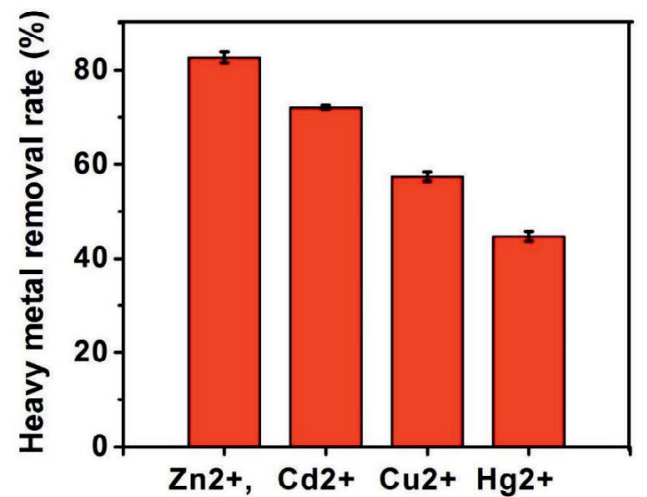

Fig. 6. Removal percentage of $\mathrm{Cu}^{2+}, \mathrm{Zn}^{2+}, \mathrm{Hg}^{2+}, \mathrm{Cd}^{2+}$ using bioflocculant. The given data represents the mean value of three independent experiments. Error bars indicate mean \pm SD. structure of the bioflocculant. Representative HR-SEM image showed well-dispersed, irregular shaped bioflocculant (Figs. 5(a)) with negatively charged zeta potential possessing best flocculating property ${ }^{22}$. The configuration of the bioflocculant were major factor involved in flocculating activity $^{21}$. During flocculation, they bonded tightly and intertwined each other due to intermolecular interaction in between them ${ }^{22,31}$. The elemental analysis for the bioflocculant were shown the presence of $\mathrm{C}, \mathrm{K}, \mathrm{Na}, \mathrm{Mg}, \mathrm{Cl}$, and $\mathrm{O}$ at particular proportions ${ }^{29}$ (Fig.s 5(b)).

\section{Heavy metals removing efficiency}

In the study, the metal ions such as $\mathrm{Zn}^{2+}$, $\mathrm{Cd}^{2+}, \mathrm{Cu}^{2+}$, and $\mathrm{Hg}^{2+}$ within the arrange of $0-50$ $\mathrm{mg} \mathrm{L-1}$ in aqueous solutions could be effectively 


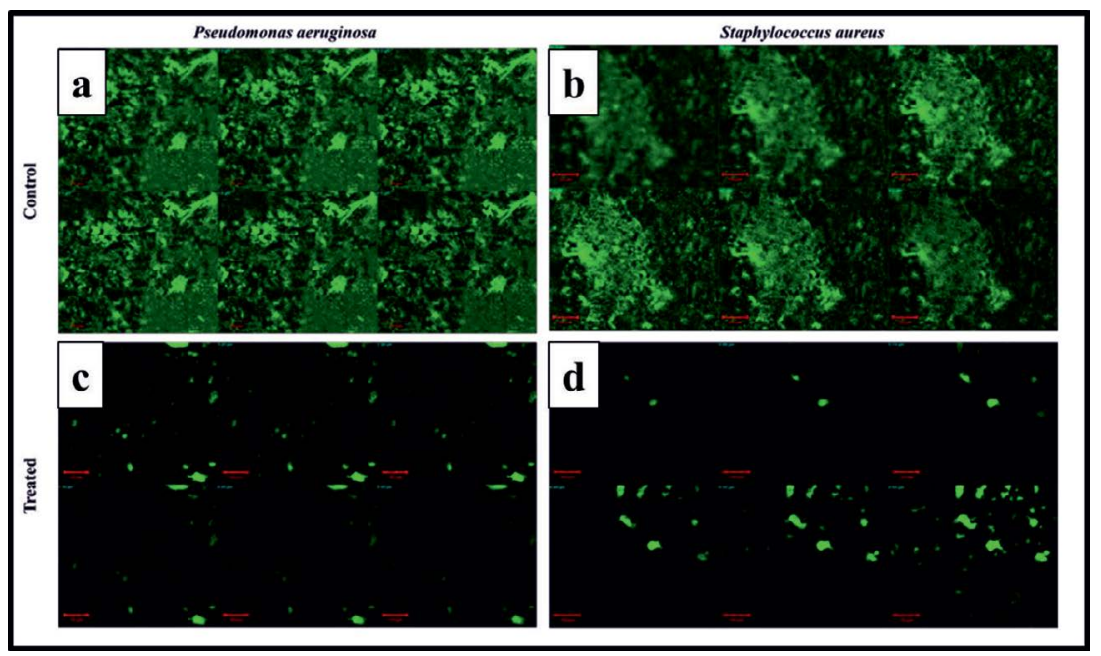

Fig. 7. (a) CLSM images of $P$. aeruginosa biofilm formation; (b) CLSM images of $S$. aureus biofilm formation; (c) CLSM images of $P$. aeruginosa biofilm formation treated with bioflocculant $(80 \mu \mathrm{g} / \mathrm{ml}) ; \quad$ (d) CLSM images of $S$. aureus biofilm formation treated with bioflocculant $(70 \mu \mathrm{g} / \mathrm{ml})$; Each experiment was replicated thrice.

flocculated by the bioflocculant. The heavy metal removing percentage achieved by the precipitated bioflocculant was $82.63 \pm 1.20,72.076 \pm 0.42$, $57.36 \pm 1.05$, and $44.7 \pm 1.053 \%$, respectively for $\mathrm{Zn}^{2+}, \mathrm{Cd}^{2+}, \mathrm{Cu}^{2+}$, and $\mathrm{Hg}^{2+}$ at optimum conditions. When compare the treated sample with untreated sample, concentration of metals in treated sample was completely reduced that showed adsorption and bioflocculating ability of bioflocculant. In addition, concentration of bioflocculant reported was very less on comparing other reported literature ${ }^{32,33}$. It was interpreted that the electronegative properties of the biological material and the metals regulated the metal-removal capacity. In addition, the interactions between metal cations and negatively charged functional group of bioflocculant such as carboxylic group, and the phosphate group found in bioflocculant (Fig. 6) were highly enhanced under constant optimum conditions ${ }^{33}$.

\section{Antibiofilm assay}

Crystal violet staining (Biofilm assay) assay are used to quantify the measurement of biofilm. Bioflocculant were showed excellent biofilm inhibition against $P$. aeruginosa where maximum reduction (73\%) were achieved at the amount of $80 \mu \mathrm{g} / \mathrm{ml}$ dose. Similarly, maximum reduction (80\%) were achieved at the amount of $70 \mu \mathrm{g} / \mathrm{ml}$ dose for S. aureus ${ }^{34}$. Control (without bioflocculant) did not show any inhibiting percentage exhibited dense bacterial population (Fig. 7). High inhibition percentage and minimum dosage requirement were showed that, bioflocculant was acting as a best antibiofilm agent. They were further visualized by confocal microscope ${ }^{35,36}$. Previously reports suggested that, bioflocculant reduced cell -cell interaction by inhibiting the attachment of bacterial cells ${ }^{37}$ and also polysaccharides found in the bioflocculant might be responsible for biofilm inhibition $^{38}$.

\section{CONCLUSION}

Out of 20 bacterial strains, bacterial strain producing highest flocculating activity were chosen for further research. The main constituents of the bioflocculant were proteins, polysaccharides as the functional groups in the bioflocculant which was being confirmed by FTIR. They were mainly responsible for its flocculating activity and antibiofilm activity. Structural characteristics of the bioflocculant were confirmed by SEM analysis. Further, monomer unit of the bioflocculant were demonstrated by GCMS. The flocculating efficiency suggested that the bioflocculant was considered as an effective material for the treatment of heavy metal removing process. High inhibition percentage and minimum dosage requirement were showed that, bioflocculant was acting as a best antibiofilm agent. 


\section{ACKNOWLEDGEMENTS}

I would like to acknowledge DST-PURSE (DST Sanction Order No- SR/FT/LS- 113/2009) for providing confocal microscopy images, and Centre of excellence in life science, Bharathidasan University, Trichy.

\section{FUNDING}

None.

\section{DATA AVAILABILITY}

All data generated during the study are included in the manuscript.

\section{ETHICS STATEMENT}

This article does not contain any studies with human participants or animals performed by any of the authors.

\section{REFERENCES}

1. Abinaya M., Vaseeharan B., Divya M., Sharmili A., Govindarajan M., Alharbi N.S., Kadaikunnan S., Khaled J.M., Benelli G. Bacterial exopolysaccharide (EPS)coated $\mathrm{ZnO}$ nanoparticles showed high antibiofilm activity and larvicidal toxicity against malaria and Zika virus vectors. J. Trace Elem. Med. Biol., 2018; 45:93103. https://doi.org/10.1016/j.jtemb.2017.10.002

2. Aljuboori A.H.R., Idris A., Abdullah N., Mohamad R. Production and characterization of a bioflocculant produced by Aspergillus flavus. Bioresour. Technol., 2013; 127:489-93. https://doi.org/10.1016/j. biortech.2012.09.016

3. Aljuboori A.H.R., Uemura Y., Osman N.B., Yusup S. Production of a bioflocculant from Aspergillus niger using palm oil mill effluent as carbon source. Bioresour. Technol., 2014; 171:66-70. https://doi.org/10.1016/j. biortech.2014.08.038

4. Azizi S., Kamika I., Tekere M. Evaluation of heavy metal removal from wastewater in a modified packed bed biofilm reactor. PloS one., 2014; 11:e0155462. https:// doi.org/10.1371/journal.pone.0155462

5. Bukhari N.A., Loh S.K., Nasrin A.B., Jahim J.M. Enzymatic hydrolysate of palm oil mill effluent as potential substrate for bioflocculant BM-8 production. Waste Biomass Valori., 2018; 1-13. https://doi. org/10.1007/s12649-018-0421-8

6. Delattre C., Pierre G., Laroche C., Michaud P. Production, extraction and characterization of microalgal and cyanobacterial exopolysaccharides. Biotechnol. Adv., 2016; 34:1159-79. https://doi. org/10.1016/j.biotechadv.2016.08.001

7. Drakou E.-M., Amorim C.L., Castro P.M., Panagiotou F., Vyrides I. Wastewater valorization by pure bacterial cultures to extracellular polymeric substances (EPS) with high emulsifying potential and flocculation activities. Waste Biomass Valori., 2018; 9:2557-64. https://doi.org/10.1016/j.biotechadv.2016.08.001
8. Feoktistova M., Geserick P., Leverkus M. Crystal violet assay for determining viability of cultured cells. Cold Spring Harbor., 2016; pdb. prot087379. https://doi. org/10.1101/pdb.prot087379

9. Fu F., Wang Q. Removal of heavy metal ions from wastewaters: a review. J. Environ. Manage., 2018; 92:407-18. https://doi.org/10.1101/pdb.prot087379

10. Giri S.S., Harshiny M., Sen S.S., Sukumaran V., Park S.C. Production and characterization of a thermostable bioflocculant from Bacillus subtilis F9, isolated from wastewater sludge. Ecotox. Environ. Safe., 2018; 121:45-50. https://doi.org/10.1016/j. ecoenv.2015.06.010

11. Gomaa E.Z. Production and characteristics of a heavy metals removing bioflocculant produced by Pseudomonas aeruginosa. Pol. J. Microbiol., 2018; 61:281-9.

12. HeN., LiY., Chen J. Production of a novel polygalacturonic acid bioflocculant REA-11 by Corynebacterium glutamicum. Bioresour. Technol., 2018; 9:99-105. https://doi.org/10.1016/j.biortech.2003.11.013

13. Kavita K., Singh V.K., Mishra A., Jha B. Characterisation and anti-biofilm activity of extracellular polymeric substances from Oceanobacillus iheyensis. Carbohyd. Polym., 2018; 101:29-35. https://doi.org/10.1016/j. carbpol.2013.08.099

14. Kim Y., Kim S.H. Released exopolysaccharide (r-EPS) produced from probiotic bacteria reduce biofilm formation of enterohemorrhagic Escherichia coli 0157: H7. Biochem. Biophys. Res. Commun. 2018; 379:324-9. https://doi.org/10.1016/j.bbrc.2008.12.053

15. Kumar C.G., Joo H.-S., Choi J.-W., Koo Y.-M., Chang C.-S. Purification and characterization of an extracellular polysaccharide from haloalkalophilic Bacillus sp. I-450. Enzyme Microb. Tech., 2004; 34:673-81. https://doi. org/10.1016/j.enzmictec.2004.03.001

16. Li C., Zhou L., Yang H., Lv R., Tian P., Li X., Zhang Y., Chen Z., Lin F. Self-assembled exopolysaccharide nanoparticles for bioremediation and green synthesis of noble metal nanoparticles. Appl. Mater. Interfaces., 2004; 9:22808-18. https://doi.org/10.1021/ acsami.7b02908

17. Lian B., Chen Y., Zhao J., Teng H.H., Zhu L., Yuan S. Microbial flocculation by Bacillus mucilaginosus: applications and mechanisms. Bioresour. Technol., 2004; 99:4825-31. https://doi.org/10.1021/ acsami.7b02908

18. Mu P., Plummer D.T. Introduction to practical biochemistry. 2004; Tata McGraw-Hill Education.

19. Nguyen T.-K., Lam S.J., Ho K.K., Kumar N., Qiao G.G., Egan S., Boyer C., Wong E.H. Rational design of singlechain polymeric nanoparticles that kill planktonic and biofilm bacteria. ACS Infect. Dis., 2004; 3:237-48. https://doi.org/10.1021/acsami.7b02908

20. Nwodo U.U., Green E., Mabinya L.V., Okaiyeto K., Rumbold K., Obi L.C., Okoh A.I. Bioflocculant production by a consortium of Streptomyces and Cellulomonas species and media optimization via surface response model. Colloids Surf. B., 2004; 116: 257-64. https://doi.org/10.1021/acsami.7b02908

21. Oliver S., Wagh H., Liang Y., Yang S., Boyer C. Enhancing the antimicrobial and antibiofilm effectiveness of silver 
nanoparticles prepared by green synthesis. J. Mater. Chem. B., 2018; 6:4124-38. https://doi.org/10.1039/ C8TB00907D

22. Pathak M., Devi A., Bhattacharyya K., Sarma H., Subudhi S., Lal B. Production of a non-cytotoxic bioflocculant by a bacterium utilizing a petroleum hydrocarbon source and its application in heavy metal removal. RSC Adv., 2018; 5:66037-46. https://doi. org/10.1039/C8TB00907D

23. Pathak M., Sarma H.K., Bhattacharyya K.G., Subudhi S., Bisht V., Lal B., Devi A. Characterization of a novel polymeric bioflocculant produced from bacterial utilization of $\mathrm{n}$-hexadecane and its application in removal of heavy metals. Front. Microbiol. Journal., 2017; 8:170. https://doi.org/10.1039/C8TB00907D

24. Patowary K., Patowary R., Kalita M.C., Deka S. Development of an efficient bacterial consortium for the potential remediation of hydrocarbons from contaminated sites. Front. Microbiol. Journal., 2017; 7:1092. https://doi.org/10.1039/C8TB00907D

25. Rendueles O., Kaplan J.B., Ghigo J.M. Antibiofilm polysaccharides. Environ. Microbiol., 2017; 15:334-46. https://doi.org/10.1039/C8TB00907D

26. Salehizadeh H., Shojaosadati S. Removal of metal ions from aqueous solution by polysaccharide produced from Bacillus firmus. Water Res., 2003; 37:4231-5. https://doi.org/10.1016/\$0043-1354(03)00418-4

27. Sathiyanarayanan G., Kiran G.S., Selvin J. Synthesis of silver nanoparticles by polysaccharide bioflocculant produced from marine Bacillus subtilis MSBN17. Colloids Surf. B., 2003; 102:13-20. https://doi. org/10.1016/j.colsurfb.2012.07.032

28. Schmid J., Sieber V., Rehm B. Bacterial exopolysaccharides: biosynthesis pathways and engineering strategies. Front. Microbiol. Journal., 2003; 6:496. https://doi.org/10.1016/j.colsurfb.2012.07.032

29. Shameer S. Biosorption of lead, copper and cadmium using the extracellular polysaccharides (EPS) of Bacillus sp., from solar salterns. 3 Biotech., 2003; 6:194. https://doi.org/10.1016/j.colsurfb.2012.07.032

30. Sun P.-F., Lin H., Wang G., Lu L.-L., Zhao Y.-H. Preparation of a new-style composite containing a key bioflocculant produced by Pseudomonas aeruginosa ZJU1 and its flocculating effect on harmful algal blooms. J. Hazard.
Mater., 2015; 284:215-21. https://doi.org/10.1016/j. jhazmat.2014.11.025

31. Tang W., Song L., Li D., Qiao J., Zhao T., Zhao H. Production, characterization, and flocculation mechanism of cation independent, $\mathrm{pH}$ tolerant, and thermally stable bioflocculant from Enterobacter sp. ETH-2. PloS one., 2015; 9: e114591. https://doi. org/10.1371/journal.pone.0114591

32. Voica D.M., Bartha L., Banciu H.L., Oren A. Heavy metal resistance in halophilic Bacteria and Archaea. FEMS Microbiol. Lett., 2015; 363. https://doi.org/10.1093/ femsle/fnw146

33. Wang L., Ma F., Qu Y., Sun D., Li A., Guo J., Yu B. Characterization of a compound bioflocculant produced by mixed culture of Rhizobium radiobacter F2 and Bacillus sphaeicus F6. World J. Microbiol. Biotechnol., 2011; 27:2559-65. https://doi. org/10.1007/s11274-011-0726-2

34. Wang Z., Shen L., Zhuang X., Shi J., Wang Y., He N. \& Chang Y.-I. Flocculation Characterization of a Bioflocculant from Bacillus licheniformis. Ind. Eng. Chem., 2015; 54:2894-901. https://doi.org/10.1021/ ie5050204

35. Wu J.-Y., Ye H.-F. Characterization and flocculating properties of an extracellular biopolymer produced from a Bacillus subtilis DYU1 isolate. Process Biochem. Journal., 2007; 42:1114-23. https://doi. org/10.1016/j.procbio.2007.05.006

36. Xiong Y., Wang Y., Yu Y., Li Q., Wang H., Chen R., He N. Production and characterization of a novel bioflocculant from Bacillus licheniformis. Appl. Environ. Microbiol., 2010; 76:2778-82. https://doi. org/10.1128/AEM.02558-09

37. Yeo J., Lee Y.-H., Jeon S.-M., Jung U.J., Lee M.-K., Jung Y.-M., Choi M.-S. Supplementation of a novel microbial biopolymer, PGB1, from new Enterobacter sp. BL-2 delays the deterioration of type 2 diabetic mice. World J. Microbiol. Biotechnol., 2010; 17:1983-90.

38. Zhang Z.-q., Bo L., Xia S.-q., Wang X.-j., Yang A.-m. Production and application of a novel bioflocculant by multiple-microorganism consortia using brewery wastewater as carbon source. J. Environ. Sci., 2007; 19:667-73. https://doi.org/10.1016/S10010742(07)60112-0 